Case report

\title{
MITRAL VALVE REGURGITATION IN TWO THOROUGHBRED STALLIONS
}

\author{
PINAR Orhan ${ }^{1}$, SANCAK Aziz Arda ${ }^{2}$, MERAL Yücel ${ }^{3}$, DALĞIN Duygu ${ }^{3 *}$ \\ ${ }^{1}$ Türkiye Jokey Kulübü, Hayvan hastanesi, Ankara, Türkiye; ${ }^{2}$ Ankara Üniversitesi, Veteriner İç \\ Hastalıklar, Ankara, Türkiye, ${ }^{3}$ Ondokuz Mayıs Üniversitesi, Veteriner İç Hastalıklar, Samsun, Türkiye
}

(Received 04 August; Accepted 04 December 2015)

Mitral valve (MV) disease is the most important valvular condition affecting athletic performance in horses. Twenty and 22 years old Thoroughbred Stallions used for breeding had suffered from increased respiratory and heart rate, poor performance and incomplete ejaculate release during covering, since three months ago. Cardiac examination projected irregular cardiac rhythm after a halt and an early-mid-systolic murmur.

Mitral regurgitation (MR) and valvular changes were visible on echocardiography. Also volume overload of the Left Atrium (LA) and Left Ventricle (LV) were observed. Color Flow Doppler echocardiography confirmed moderate mitral valve regurgitation. A band-like fibrous and nodular degeneration of the left coronary leaflet was present. There was minimal secondary left ventricular remodeling of the apex of the left ventricle due to chronic volume overload.

The therapeutic attempts included Quinapril and Furosemide. In these cases, normally no structural effect could be achieved, but clinical improvement and successful covering sessions were obtained, and when the therapy was terminated, clinical problems reappeared. In conclusion, in horses with MR, early diagnosis and appropriate therapy with Quinapril promises a reasonable performance.

Key words: Age, Echocardiography, Horse, Mitral Valve, Quinapril

\section{INTRODUCTION}

Mitral valve (MV) disease is the most important valvular condition affecting athletic performance. Horses of all ages can be affected, but chronic degenerative disease is most frequently seen in middle-aged or older horses [1].

\section{CASE PRESENTATION}

Twenty and 22 years old Thoroughbred Stallions used for breeding had suffered from increased respiratory and heart rate, poor performance and incomplete ejaculate release during covering, since three months ago. The clinical examination revealed

\footnotetext{
*Corresponding author: e-mail: duyguc@omu.edu.tr
} 
particular emphasis on the cardiovascular system. Determination the cause of poor performance is difficult, because many problems manifested in horses may be based on multiple concurrent problems. The examination consists of a careful observation, thus a distended jugular vein is a very important finding for ventral edema. However, the position of the head will alter the degree of distension. The jugular vein will fill in a normal animal when it lowers its head, because the vein is then ventral to the right atrium. One or both jugular veins may also be distended when venous return is impaired by a thoracic mass or even when there is a large pleural effusion. Edema of the distal limbs and ventral abdomen in the case of right heart insufficiency, tricuspidal stenosis/insufficiency, and pulmonary valve stenosis/insufficiency can often be seen.

During the cardiac auscultation irregular cardiac rhythm was heard immediately after canter. Heart rate at rest ranged from 42 to 45 beats / min and recovery after pulling up from canter was within the physiological time (after 10-15 min).

During auscultation, a loud musical and vibrant early-mid-systolic murmur due to the rapid deceleration of blood in the left ventricle at the end of passive early diastolic filling, which is characteristic for mitral valve insufficiency, was audible. Immediately after pulling up from canter, the murmur of mitral regurgitation was greatly reduced in intensity, although it returned rapidly as the heart rate fell.

\section{Echocardiographic examination and findings}

Esaote MyLab Vet 30 ultrasound system with a $2.5 \mathrm{MHz}$ annular phased array transducer was used for all echocardiographic examinations. The maximum depth for B- and M-mode imaging was $27-30 \mathrm{~cm}$. Standard long and short- axis twodimensional real-time and M-mode echocardiograms were evaluated for mitral valve insufficiency in standing non sedated stallions. Echocardiography can be helpful to identify gross valvular lesions. Mitral regurgitation (MR) and a valvular change were visible on echocardiography. A left atrial diameter of $>13.5 \mathrm{~cm}$ and a left ventricular diameter of $>13.4 \mathrm{~cm}$ were considered enlarged [2,3].

Continuous-wave and color-flow Doppler echocardiograms were performed to determine the stroke volume and cardiac output, as well as the effect of quinapril medication on this variables (Table 1). Also, LVD measurements are presented in Table 2. For cardiac output measurements the long-axis view of the left ventricular outflow tract and aorta were obtained by B-mode echocardiography. The color flow Doppler was placed in the center of the aorta above the aortic valve where it shows the fastest blood flow [4].

Table 1. Values measured from 2-D, M-mode and Doppler Echocardiography of 2 stallion with mitral valve insufficiency before and after treatment with Quinapril.

\begin{tabular}{ccccccc}
\hline No & $\begin{array}{c}\text { LA diameter } \\
(\mathbf{c m})\end{array}$ & $\begin{array}{c}\text { LV diameter } \\
(\mathbf{c m})\end{array}$ & FS (\%) & VTI $\left(\mathbf{c m}^{2}\right)$ & SV (ml) & CO (1/min) \\
\hline 1 & $13.2-13.2$ & $14.1-13.8$ & $36-36$ & $166-118$ & $767-886$ & $32.2-37.2$ \\
2 & $13.4-13.5$ & $14.9-15.0$ & $34-36$ & $115-115$ & $719-808$ & $32.3-36.3$ \\
\hline
\end{tabular}


Table 2. Dimension of the left ventricle from the right para-strenal view

\begin{tabular}{lcccc}
\hline Dimension & $\begin{array}{c}\text { Findings } \\
(\mathbf{c m})\end{array}$ & $\begin{array}{c}\text { Average } \\
(\mathbf{c m})\end{array}$ & Max & Min \\
\hline LVDS & 8,2 & 7.5 & 9.1 & 5.8 \\
LVDd & 14,6 & 11.9 & 13.5 & 9.7 \\
IVSs & 5,0 & 4.2 & 5.2 & 3.2 \\
IVSd & 2,9 & 2.9 & 3.7 & 2.3 \\
LVFWs & 3,3 & 3.8 & 4.6 & 3.2 \\
LVFWd & 2,8 & 2.2 & 2.6 & 1.7 \\
FS\% (R) & 34 & 36.9 & 45.0 & 28.0 \\
FS\% (L) & 36 & 38.0 & 47.0 & 27.0 \\
\hline
\end{tabular}

LVDs - Left ventricular diameter at end-systole, LVDd - Left ventricular diameter at end diastole, IVSs - Interventricular septal thickness at end-diastole, LVFWs - Left ventricular free-wall thickness at end-systole, LVFWd - Left ventricular free-wall thickness at end-diastole, FS\% - Fractional shortening in 2DE - Two-dimensional image.

Also the volume overload of the aortic and pulmonary valves was observed. Examination of the structure and motion of the MV, in long- and short-axis views was enabled from the right and left parasternal positions. In the long-axis views, nodular thickening of the valve was seen (Fig. 1) as a prolapse or flail of a leaflet. Measurements were made from both sides of the chest. LV diameter is measured from the right parasternal short-axis view at the level of the chordae tendineae, using 2-DE to guide the position of the M-cursor. The small increase in LVIDdiast suggested that MR was progressing. Color Flow Doppler echocardiography confirmed the presence of moderate mitral valve regurgitation (Fig. 2).
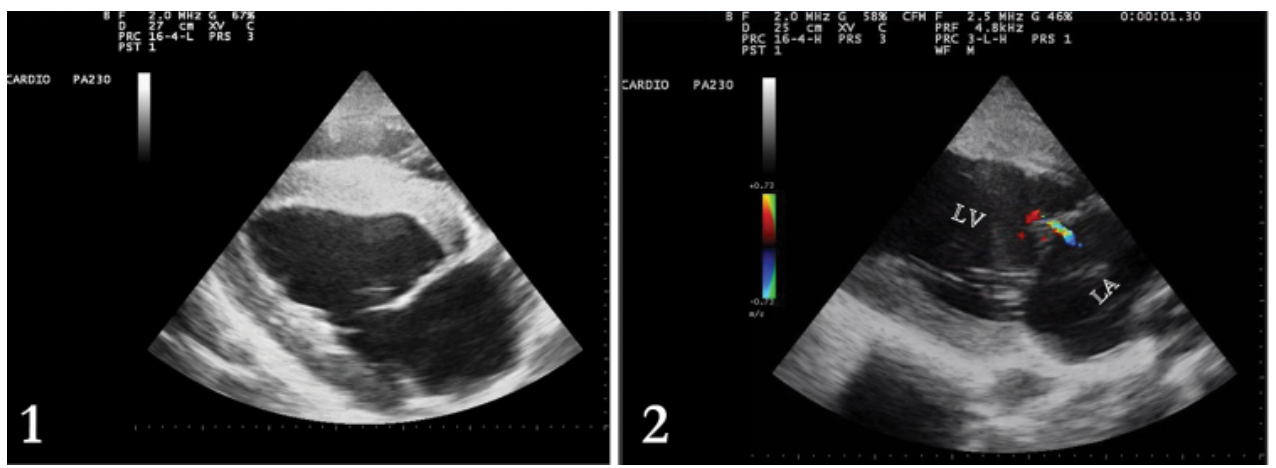

Fig 1. Long axis views nodular thickening of the valve

Fig 2. Moderate mitral valve regurgitation

A band-like fibrous and nodular degeneration of the left coronary leaflet was present. There was minimal secondary left ventricular remodeling of the apex of the left ventricle - due to chronic volume overload (Fig. 3). 
The different parameters were calculated as follows:

Stroke Volume (SV): VTI (Velocity time integral) x CSA (Cross Sectional Area)

CSA is the area of a valve or vessel. CSA $=\pi(3.14) \times[\mathrm{r}(\mathrm{d} / 2)]^{2}$

$\mathrm{d}=$ Aortic diastolic diameter (Fig 4)

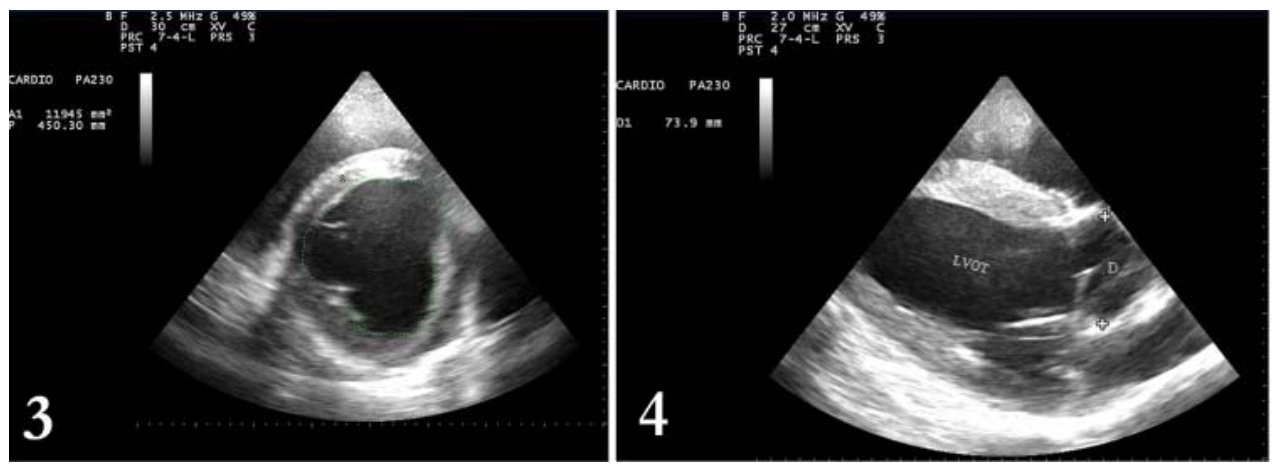

Fig 3. Secondary left ventricular remodeling of the apex of the left ventricle - due to chronic volume overload.

Fig 4. Aortic diastolic diameter.

VTI is the area under the modal velocity envelope. (Fig 5)

Cardiac Output: SV x Heart Rate (HR)

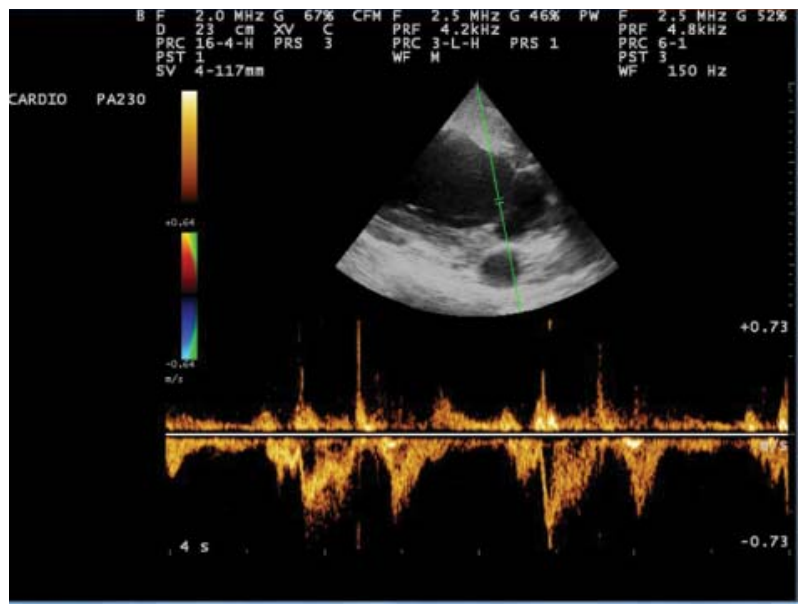

Fig 5. Area under the modal velocity envelope

\section{Therapy}

The etiology of mild mitral regurgitation (MR) in our two horses could not be identified. Ideally, although difficult, one should attempt to measure jet width and depth at the origin and correlate the measurements with LA and LV chamber size. 
The appearance of a flow disturbance can provide qualitative information about the severity of regurgitation $[2,7]$.

enalapril is poorly absorbed by the equine gastrointestinal tract [8,9], and quinapril has been found to be the most potent of all available ACE inhibitors in binding to tissue such as the arterial wall and heart, which is an important component of the mechanism of action and its favorable effects in cardiovascular disorders [7,10].

Quinapril was used for ACE inhibition in these horses at a dose of $100 \mathrm{mg}$ per day with furosemide. After treatment, the breeding ability was restored to previous levels.

\section{DISCUSSION}

The aortic valve is the commonest site for valvular pathology, particularly in the middle-aged and older horses as the present cases and murmurs of MR are present in around $2.9-3.5 \%$ of the otherwise healthy general horse population and the prevalence is much higher in racing Thoroughbreds $[1,2,7]$. Generally, large horses have larger cardiac dimensions than smaller animals, and fit, athletic horses have larger chambers compared to horses which are not trained.

Because severe MR may result in dilation in the pulmonary artery and pulmonary hypotension and also regarding the reports of sudden deaths due to PA rupture, these horses have impaired working ability $[3,4,8,11]$

In these two cases, the mild increase in LVIDdiast suggested that MR was in fact progressing. However, LAsyst, LV FS\% and the other measurements showed no significant changes. The symptoms may have been related to respiratory problems, but are also typically found in horses with clinically significant MR [2,10]. The MR was graded into insignificant, mild, moderate and severe. With this system, the left atrium is subdivided into thirds for grading the extent of turbulent flow. As previously reported, horses with severe MR carry a poor prognosis and horses with heart failure rarely recover $[2,11,12,13]$.

The parameters LAsyst and LVIDdiast were chosen for analysis, because volume overload was expected to increase the left atrial and/or left ventricular diameters $[14,15]$. Both diameters were measured from the left para-sternal long-axis view, as there were technical limitations of ultrasound depth in order to display the left atrium from the right para-sternal view. However, the most sensitive indicator of left atrial enlargement is the maximal diameter measurement obtained from the left para-sternal two chamber view of the left atrium and ventricle [14-16]. While enlargement of the left atrium and ventricle (i.e.increased LAsyst and LVIDdiast) are expected. A sign of congestion due to $\mathrm{MR}$, is the increase in measured $\mathrm{LV} \% \mathrm{FS}$. $\mathrm{LV} \% \mathrm{FS}$ would be expected to decrease in end-stage myocardial failure or if primary myocardial contractility is an important factor in valvular dysfunction [14]. 
In mild chronic MR, ACE inhibitors and other vasodilators do not delay LV dilation or MR progression and so have no role in asymptomatic MR with preserved LV function $[17,18]$. The hemodynamic consequence of valvular insufficiency is volume overload. So if LV dilation or dysfunction is present, ACE inhibition is beneficial for metabolic adaptation. Orally administred enalapril is poorly absorbed in horses $[8,9]$. In human beings and small animals, ACE inhibitors are usually used for longterm application [17]. But a beneficial effect on left ventricular performance in chronic mitral regurgitation could also be seen after a single dose of quinapril in man [17], and after short-term treatment (4 weeks) in dogs [19,20]. In these horses, we used quinapril for 6 weeks concurrent with furosemide $(0.5 \mathrm{mg} / \mathrm{lb}$ of body weight), as indicated $[12,21,22]$, and we observed significant beneficial effects on systolic cardiac variables as an increased stroke volume and cardiac output. Also, increase in reproductive capacity was observed from the owner's subjective opinion. After therapy, the horses with mitral valve insufficiency showed an increase in stroke volume and cardiac output as well as a reduced mitral regurgitation.

\section{CONCLUSION}

In these two cases no structural improvement was achieved as expected, but therapy provided a successful breeding use and clinical improvement with quinapril. When therapy ceased symptoms relapsed.

In conclusion, early diagnosis and accurate therapy with quinapril and furosemide promises reasonable performance in horses with MR which do not have a reasonable quality of life, thus emphasis on cardiac examination in horses is essential.

\section{Authors' contributions}

OP carried out the echocardiographic examinations and drafted the manuscript. AAS supervised the clinical examinations and drafted the manuscript. YM and DD evaluated the data and drafted the manuscript.

\section{Declaration of conflicting interests}

The author(s) declared no potential conflicts of interest with respect to the research, authorship, and/or publication of this article.

\section{REFERENCES}

1. Morris EH, Seeherman HJ: Clinical evaluation of poor performance in the racehorse: the results of 275 evaluations. Equine Vet J 1991, 23: 169-174. 
2. Reef VB, Bain FT, Spencer PA: Severe mitral regurgitation in horses: clinical, echocardiographic and pathological findings. Equine Veterinary Journal 1998, 30: 18-27.

3. Stadler P, Robine F: b-mode echocardiographic measurement of heart dimensions in warm blooded horses without heart disease. Pferdeheilkunde 1996, 12: 35-43.

4. Blissit KJ, Bonagura JD: Pulsed wave Doppler echocardiography in normal horses. Equine Vet. J 1995, 19: 38-46.

5. Zucca E, Ferrucci F, Stancari G, Saporiti T, Ferro E : The prevalence of cardiac murmurs among standardbred racehorses presented with poor performance. J Vet Med Sci. 2010, 72(6):781-5.

6. Budzynka M, Kamieniak J, Krupa W, Soltys L: Behavioural and physiological reactivity of mares and stallions evaluated in performance tests. Acta Veterinaria-Beograd 2014, 64 (3): 327-337.

7. Marr CM, Bowen M: Dysrhythmias: assessment and medical management. In: Reef VB, Marr CM (Ed): Cardiology of the Horse. 2nd ed. Saunders; 2010, 219-311.

8. Sleeper M, McDonnell Sue M, John J, Reef B: Chronic oral therapy with enalaprill in normal ponies. Journal of Veterinary Cardiology 2008, 10, 111-115.

9. Muir WW, Sams RA, Hubbell JA, Hinchcliff KW, Gadawski J: Effects of enalaprillat on cardiorespiratory, hemodynamic, and hematologic variables in exercising horses. Am J Vet Res 2001, 62: 1008-1013.

10. Frank GJ, Knapp LE, Olson SC, Phelps MC, Quade MM, Rieger MM, Sedman AJ: Overview of quinapril, a new ACE inhibitor. J. Cardiovasc. Pharmacol 1990, 15 (2): 14-23.

11. Young LE, Rogers K, Wood JLN: Heart murmurs and valvular regurgitation in thoroughbred race-horses: epidemiology and associations with athletic performance. Journal of the American Veterinary Medical Association 2008, 22:418-426.

12. Davis JL, Gardner SY, Schwabenton B, Breuhaus BA: Congestive heart failure in horses: 14 cases (1984-2001). Journal of the American Veterinary Medical Association 2002, 220: $1512-1515$.

13. Marr CM: Mitral insufficiency. In: Marr, C.M. (Ed.), Cardiology of the Horse. Saunders, London, 1999, 245-247.

14. Bonagura JD, Reef VB: Disorders of the cardiovascular system. Echocardiography. In: Reed SM, Bayly WM, Sellon DC (Eds.), Equine Internal Medicine, second ed. Saunders, Philadelphia, USA, 2004, 390-391.

15. Long KJ, Two-dimensional and M-mode echocardiography. Equine Vet 1992, 4:303-310.

16. Blissit KJ, Bonagura JD: Pulsed wave Doppler echocardiography in normal horses. Equine Vet. J 1995, $19: 38-46$.

17. Riegger AJG: ACE inhibitors in early stages of heart failure. Circulation 1993, 87(4):117119.

18. Schon HR: Hemodynamic and morphologic changes after long-term angiotensin converting enzyme inhibition in patients with chronic valvular regurgitation. J. Hyperten 1994, 12: 95-104.

19. Martinez-Alcaine MA, Ynaraja E. Corbera JA, Montoya JA: Effect of short-term treatment with bumetanide, quinapril and low-sodium diet on dogs. Aust Vet J 2001, 79:102-105.

20. Morisse B, Kersten U: Treatment of heart failure in dogs with ACE inhibitors: comparison of quinapril and captopril. Tiera" rztl. Praxis 1995, 5: 489-496. 
21. Gehlen H, Vieht JC, Stadler P: Effects of the ACE inhibitor quinapril on echocardiographic variables in horses with mitral valve insufficiency. J Vet Med A Physiol Pathol Clin Med 2003, 50(9):460-465.

22. Gehlen H, Stadler P: Comparison of systolic cardiac function before and after treatment of atrial fibrillation in horses with and without additional cardiac valve insufficiencies. Vet

Res Commun 2004, 28(4): 317-29.

\section{REGURGITACIJA MITRALNOG ZALISTKA KOD DVA PUNOKRVNA PASTUVA}

PINAR Orhan, SANCAK Aziz Arda, MERAL Yücel, DALĞIN Duygu

Oboljenje mitralnog zalistka predstavlja najznačajniji poremećaj na nivou srčanih zalistaka koji utiče na atletske performanse konja. Dva punokrvna priplodna pastuva, starosti 20 i 22 godine, su u protekla tri meseca imala povišen respiratorni i srčani puls, slabe performanse i nepotpunu ejakulaciju tokom pripusta. Kardiološki pregled je ukazao na nepravilan srčani ritam i rani sistolni šum. Mitralna regurgitacija (MR) i promene na zaliscima su bili uočljivi tokom ehokardiografije. Takođe, uočeno je zapreminsko preopterećenje leve predkomore (LA) i leve komore (LV). Kolor dopler ehokardiografija je potvrdila umerenu regurgitaciju mitralnog zaliska. Takođe je uočena trakasta fibrozna i nodularna degeneracija levog koronarnog zaliska kao i minimalno sekundarno remodeliranje apeksa leve srčane komore usled hroničnog preopterećenja.

Terapeutski pokušaji su uključivali Quinapril i Furosemid. U oba slučaja nije postignut strukturni efekat, ali su postignuti kliničko poboljšanje i uspešan pripust. Nakon obustave terapije klinički problemi su se ponovo vratili. U zaključku, kod konja sa MR rana dijagnoza i adekvatna terapija sa Quinaprilom obećavaju zadovoljlavajuće performanse. 